\title{
A CASE REPORT OF CASTLEMAN DISEASE
}

\author{
Shruti Jain 1 , Anurag Agrawal2, Lalit Singh 3 , Rajeev Tandon 4
}

${ }_{1}^{1}$ Assistant Professor, Department of Respiratory Medicine, Sri Ram Murti Smarak Institute of Medical Sciences, Bhojipura, Bareilly, Uttar Pradesh.

2Postgraduate Student, Department of Respiratory Medicine, Sri Ram Murti Smarak Institute of Medical Sciences, Bhojipura, Bareilly, Uttar Pradesh.

${ }^{3}$ Professor, Department of Respiratory Medicine, Sri Ram Murti Smarak Institute of Medical Sciences, Bhojipura, Bareilly, Uttar Pradesh.

${ }^{4}$ Professor, Department of Respiratory Medicine, Sri Ram Murti Smarak Institute of Medical Sciences, Bhojipura, Bareilly, Uttar Pradesh.

HOW TO CITE THIS ARTICLE: Jain S, Agrawal A, Singh L et al. A case report of Castleman disease. J. Evolution Med. Dent. Sci. 2018;7(33):3724-3727, DOI: 10.14260/jemds/2018/836

\section{PRESENTATION OF CASE}

Patient aged 17 years, male was admitted with c/o breathlessness for 1 month, dry cough for 1 month, loss of appetite for 1 month, haemoptysis for 1 day, epistaxis for 1 day. No h/o recent contact with active tuberculosis, no h/o any addiction, no h/o anti-tubercular drug/ diabetes mellitus/ hypertension. General examination showed left supraclavicular, left axillary LN enlargement and swelling over left-sided anterior chest wall. On systemic examination of respiratory system, left side movement was found to be diminished and bulging was seen. Palpation- Trachea shifted towards right side and decreased vocal fremitus on the left side. Auscultation- Vesicular breath sounds were absent on the left side with no added sound.

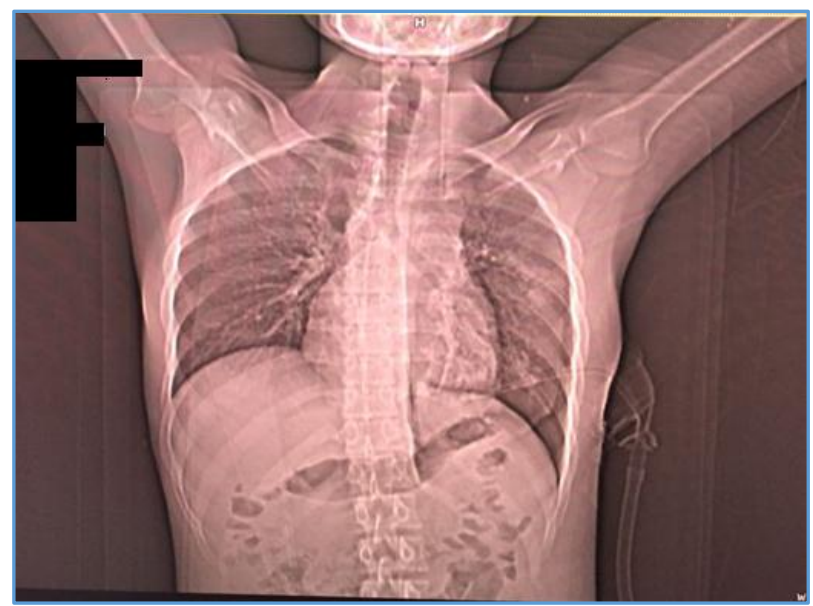

Chest X-Ray

\section{DIFFERENTIAL DIAGNOSIS1}

1. Human herpesvirus-8 (HHV-8). ${ }^{2}$

2. Epstein-Barr virus (EBV). ${ }^{3}$

3. Inflammation and adenopathy caused by other uncontrolled infections. ${ }^{4}$

4. Systemic lupus erythematosus.

'Financial or Other Competing Interest': None.

Submission 08-02-2018, Peer Review 15-03-2018,

Acceptance 21-03-2018, Published 13-08-2018.

Corresponding Author:

Dr. Rajeev Tandon,

Assistant Professor

Department of Respiratory Medicine,

Sri Ram Murti Smarak Institute of Medical Sciences,

Bhojipura, Bareilly-243202, Uttar Pradesh.

E-mail: montoo1969@gmail.com

DOI: $10.14260 /$ jemds $/ 2018 / 836$

\section{(c) (i) $(9)$}

5. Rheumatoid arthritis.

6. ALPS.

7. Lymphoma.

8. Multiple myeloma.

9. Castleman disease (CD).

\section{CLINICAL DIAGNOSIS}

Initial blood investigation showed $\mathrm{Hb}-13.5$, TLC- 21,300, DLC- P82, L16, M3, Platelet- 2.40 lacs $/ \mathrm{mm}^{3}$, Urea- 29, Creatinine- 0.8, Na- 135, K- 3.6, Viral markers- Non-reactive. Pleural fluid examination showed Colour- haemorrhagic, PH/reaction- acidic, TLC- 22,500, DLC- P30, L70, Mesothelial cells- present, RBCs- 25 - 30/hpf, pleural fluid biochemical examination- Glucose- $19 \mathrm{mg} / \mathrm{dL}$, Total protein- $3.9 \mathrm{~g} / \mathrm{dL}$, Albumin- $2.6 \mathrm{gm} / \mathrm{dL}$ and ADA- $319 \mathrm{U} / \mathrm{L}$. Pleural fluid for M cell- atypical cell present? lymphoid origin.

\section{Management of $1^{\text {st }}$ Admission}

Pleural tapping was done, and $30 \mathrm{~mL}$ haemorrhagic fluid was aspirated and sent for investigation purpose.

To relieve dyspnoea, intercostal drainage was done on $3 / 12 / 16$. Symptomatic management was done till reports were awaited. Steroid added.

CECT thorax shows heterogeneous tissue in the left ant. chest wall in costochondral region, enlarged axillary, B/L supraclavicular and left internal mammary nodes, mild pericardial effusion, mild confluent air space opacities with adjacent ground glass densities in the left lung predominantly could be infective or infiltrative? lymphadenopathy.

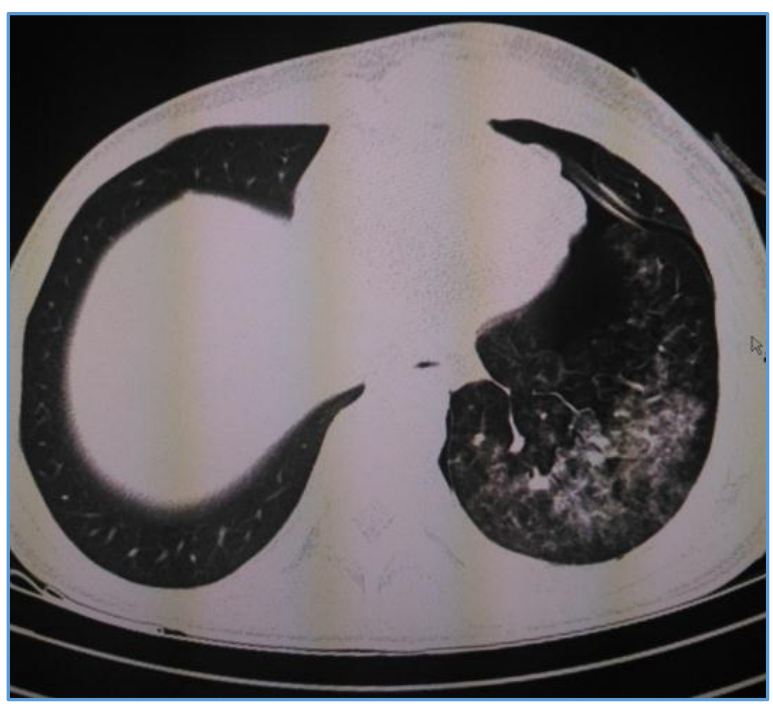

Ground Glass Opacities 


\section{PATHOLOGICAL DISCUSSION}

FNAC from left supraclavicular and left axillary LN on $5 / 12 / 16$.
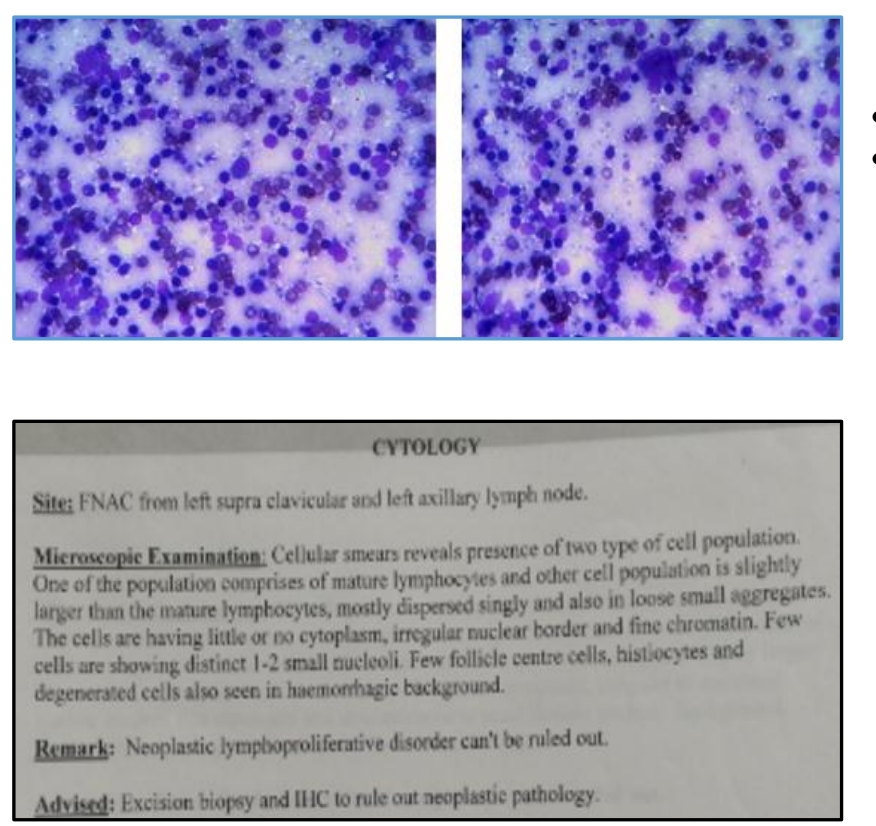

Biopsy of Left Cervical Lymph Node showed Castleman Disease

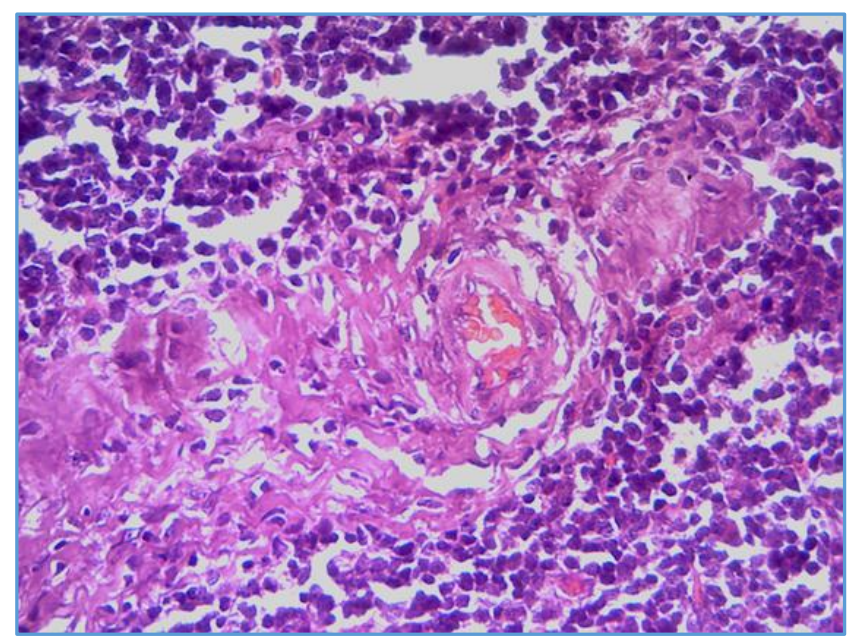

\section{HISTOPATHOLOGY REPORT}

Specimen- Left cervical lymph node.

Gross- Received an irregular greyish brown tissue pieces measuring $2.5 * 2.0 * 0.5 \mathrm{~cm}$. Cut surface showed 3 lymph nodes measuring 0.2 to $1.2 \mathrm{~cm}$ in diameter with homogeneous greyish brown cut surface, whole embedded.

\section{Microscopic Examination}

Sections from the lymph nodes show involuted lymphoid follicles with hyalinised vessels. The interfollicular areas show proliferation of lymphocytes and plasma cells and many vessels surrounded by cuffs of collagen.

Impression- Left Cervical Lymph Node- S/O Castleman Disease.

\section{Management}

Course in Hospital: No residual fluid, lung expanded, asymptomatic.
Nodes are gone both clinically and radiologically by the time patient makes arrangement for biopsy.

Patient's intercostal drainage was removed on 10/12/16 and he was symptomatically better relieved of dyspnoea and was discharged on $11 / 12 / 16$ with the advice of regular follow-up.

\section{- Readmission}

- Patient came into OPD with c/o Breathlessness increased for 10 days, dry cough increased for 10 days, fever for 5 days, haemoptysis for 1 day, epistaxis for 1 day and vomiting for 1 day.

- He was admitted for the same on $13 / 1 / 17$. Initial investigation showed Hb- 6.3, TLC- 9800, DLC- P23, L74, M3, Platelet- 35,000, Urea- 232, Creatinine- 2.6, Na- 136 and K- 5.8.

- $\quad$ S. bilirubin TDI- 1

- $\quad$ S. protein- 5.7

- $\quad$ Albumin- 3.8

- $\quad$ SGOT- 65

- $\quad$ SGPT- 16

- SAP- 145

- PT- $15 / 19.8$

- $\quad$ APTT- $40 / 40$

- GBP showed RBCs- predominantly normocytic normochromic and WBCs- TLC within normal limits with lymphocytosis.

- Platelet reduced.

- Bone Marrow examination was done.

- Patient had developed multi-organ dysfunction as platelets, coagulation profile and acute kidney injury.

- Pleural fluid on 13/1/16- Pleural Fluid ADA- 140 U/L.

- $\quad$ Pleural fluid for M cell- Atypical cells present.

- (? Lymphoid in origin), PCR- MTB DNA- Detected.

- Patient succumbed on $14 / 1 / 17$ to multiorgan dysfunction.

- Patient survived for just one day after second admission.

\section{FINAL DIAGNOSIS}

This case report brings to light the importance of obtaining definitive histological diagnosis in patients presenting with lymphadenopathy and systemic symptoms. Multicentric Castleman's disease is a relatively uncommon cause for such a presentation. ${ }^{5}$ Though, clinically synonymous with lymphoma, it is an entity that is distinct from malignant lymphoproliferative disorders histologically and prognostically. ${ }^{6}$ It may be borne in mind as a differential diagnosis in lymphadenopathic presentations with symptoms of systemic involvement. ${ }^{7}$

\section{DISCUSSION WITH MANAGEMENT}

- Castleman disease (CD) is a rare disease of lymph nodes and related tissues. ${ }^{8}$ It is a heterogeneous group of lymphoproliferative disorders that are sometimes associated with human immunodeficiency virus (HIV) and human herpesvirus 8 (HHV-8). ${ }^{9}$

- Although, Castleman disease is not cancerous, it may also be associated with malignancies such as Kaposi sarcoma, non-Hodgkin's lymphoma and Hodgkin's lymphoma. ${ }^{10}$ 
Localised versus Multicentric Castleman Disease

- Localised or Unicentric- Confined to single group of nodes, usually chest or abdomen. ${ }^{11}$

- Multicentric- More than one group; also, organs having lymphoid tissue; associated with HIV, HHV-8 and EBV; may transform to lymphoma. ${ }^{12}$

\section{Localised versus Multicentric Castleman Disease}

- Localised or Unicentric- Confined to single group of nodes, usually chest or abdomen. ${ }^{13}$

- Multicentric- More than one group; also, organs having lymphoid tissue; associated with HIV, HHV-8 and EBV; may transform to lymphoma. ${ }^{14}$

\section{Epidemiology}

Rare, Mean age 50 - 65, Person with HIV are younger, 50-65\% cases are male. 15

Incidence has increased with ART. 16

Presentation- Unicentric or localised Castleman disease is generally asymptomatic, but may cause the following symptoms.

- $\quad$ Localised lymphadenopathy with resultant compressive symptoms. ${ }^{17}$

- $\quad$ Systemic symptoms like those of MCD.18

\section{Treatment- Unicentric}

Surgery is usually curative. In patients whose lesions cannot be completely resected, outcomes remain favourable. ${ }^{19}$ Partially resected masses may remain stable and asymptomatic for many years.

Patients with unresectable diseases with compressive symptoms can be treated as described for HIV-negative MCD. 20

Systemic steroids can provide symptomatic relief, but do not predictably reduce tumour size. ${ }^{21}$

Radiation therapy with 30 - 45 Gy can result in complete and partial remission rates of $40 \%$ and $10 \%$ respectively, but can cause radiation-induced fibrosis that makes subsequent surgical intervention more difficult. ${ }^{22}$

\section{Treatment Multicentric}

IL-6-directed therapy. Especially in HIV/ HHV-8-negative patients with mild symptoms and no organ failure, immunotherapy with monoclonal antibodies directed at IL-6 (siltuximab) or the IL-6 receptor (tocilizumab) was reported to yield a 2-year overall survival rates and relapse-free rates of $94 \%-95 \%$ and $79 \%-85 \%$, respectively. ${ }^{23,24}$

\section{REFERENCES}

[1] Frizzera G. Castleman's disease and related disorders. Semin Diagn Pathol 1988;5(4):346-64.

[2] Castleman B, Iverson L, Menendez VP. Localized mediastinal lymphnode hyperplasia resembling thymoma. Cancer 1956;9(4):822-30.

[3] Sarrot-Reynauld F. Castleman's disease. Orphanet encyclopaedia. August 2001 http://www.orpha.net/data/patho/GB/ukcastleman. pdf.

[4] Herrada J, Cabanillas F, Rice L, et al. The clinical behaviour of localized and multicentric Castleman disease. Ann Intern Med 1998;128(8):657-62.
[5] Yu L, Tu M, Cortes J, et al. Clinical and pathological characteristics of HIV- and HHV-8-negative Castleman disease. Blood 2017;129(12):1658-68.

[6] Yoshizaki K, Matsuda T, Nishimoto N, et al. Pathogenic significance of interleukin-6 (IL-6/BSF-2) in Castleman's disease. Blood 1989;74(4):1360-7.

[7] Leger-Ravet MB, Peuchmaur M, Devergne 0, et al. Interleukin-6 gene expression in Castleman's disease. Blood 1991;78(11):2923-30.

[8] Stone K, Woods E, Szmania SM, et al. Interleukin-6 receptor polymorphism is prevalent in HIV-negative Castleman disease and is associated with increased soluble interleukin-6 receptor levels. PLoS One 2013;8(1):e54610.

[9] Talat N, Belgaumkar AP, Schulte KM. Surgery in Castleman's disease: a systematic review of 404 published cases. Ann Surg 2012;255(4):677-84.

[10] Dupin N, Diss TL, Kellam P, et al. HHV-8 is associated with a plasmablastic variant of Castleman disease that is linked to HHV-8-positive plasmablastic lymphoma. Blood 2000;95(4):1406-12.

[11] [Guideline] Fajgenbaum DC, Uldrick TS, Bagg A, et al. International, evidence-based consensus diagnostic criteria for HHV-8-negative/idiopathic multicentric Castleman disease. Blood 2017;129(12):1646-57.

[12] Casper C. The aetiology and management of Castleman disease at 50 years: translating pathophysiology to patient care. Br J Haematol 2005;129(1):3-17.

[13] Barker R, Kazmi F, Stebbing J, et al. FDG-PET/CT imaging in the management of HIV-associated multicentric Castleman's disease. Eur J Nucl Med Mol Imaging 2009;36(4):648-52.

[14] Bower M. How I treat HIV-associated multicentric Castleman disease. Blood 2010;116(22):4415-21.

[15] Bower M, Powles T, Williams S, et al. Brief communication: rituximab in HIV-associated multicentric Castleman disease. Ann Intern Med 2007;147(12):836-9.

[16] Wong RS, Casper C, Munshi N, et al. A multicenter, randomized, double-blind, placebo-controlled study of the efficacy and safety of siltuximab, an antiinterleukin-6 monoclonal antibody, in patients with multicentric Castleman's disease. Blood 2013;122(21):505.

[17] Sobas MA, Vence AN, Arias DJ, et al. Efficacy of bortezomib in refractory form of multicentric Castleman disease associated to poems syndrome (MCD-POEMS variant). Ann Hematol 2010;89(2):2179.

[18] Wang X, Ye S, Xiong C, et al. Successful treatment with bortezomib and thalidomide for POEMS syndrome associated with multicentric mixed-type Castleman's disease. Jpn J Clin Oncol 2011;41(10):1221-4.

[19] Scott D, Cabral L, Harrington WJ Jr. Treatment of HIVassociated multicentric Castleman's disease with oral etoposide. Am J Hematol 2001;66(2):148-50.

[20] Chronowski GM, Ha CS, Wilder RB, et al. Treatment of unicentric and multicentric Castleman disease and the role of radiotherapy. Cancer 2001;92(3):670-6.

[21] Talat N, Schulte KM. Castleman's disease: systematic analysis of 416 patients from the literature. Oncologist 2011;16(9):1316-24. 
[22] Beck JT, Hsu SM, Wijdenes J, et al. Brief report: alleviation of systemic manifestations of Castleman's disease by monoclonal anti-interleukin- 6 antibody. N Engl J Med 1994;330(9):602-5.

[23] Kawabata H, Tomosugi N, Kanda J, et al. Antiinterleukin 6 receptor antibody tocilizumab reduces the level of serum hepcidin in patients with multicentric Castleman's disease. Haematologica 2007;92(6):857-8.
[24] van Rhee F, Fayad L, Voorhees P, et al. Siltuximab, a novel anti-interleukin-6 monoclonal antibody, for Castleman's disease. J Clin Oncol 2010;28(23):3701-8. 